УдК 005.95:331.5:331.101.3

DOI: $10.15673 /$ fie.v12i2.1739

Козак К.Б.

кандидат економічних наук, доцент кафедра менеджменту та логістики E-mail: kozakkate.coach@gmail.com ORCID ID: 0000-0002-8099-6607
Левчук Ю.С.

старший викладач

кафедра менеджменту та логістики

E-mail: Levchyk_onaft@ukr.net

ORCID ID: 0000-0001- 7417-2866

Прунчак М.М.

студент 4 курсу фракультету менеджменту, маркетингу та логістики

Одеська національна академія харчових технологій

вул. Канатна 112, м. Одеса, Україна, 65039

E-mail: tiktonik199730@gmail.com

ORCID ID: 0000-0001-9713-7692

\title{
ДОСЛІДЖЕННЯ ОСНОВНИХ ПРОБЛЕМ ЩОДО МОТИВАЦІЇ ПРАЦІВНИКІВ ПІДПРИЄМСТВА
}

Протягом багатьох років вітчизняні компанії не в достатній мірі використовували системи мотивації на відміну від закордонних. Відомо, що існуючі способи стимулювання працівників вимагають індивідуального підходу і доопрацювань. В цій статті проаналізовано основні проблеми щодо персональної та групової мотивації персоналу і розглянуті заходи щодо їх удосконалення. Світова практика свідчіть, що теорії мотивації, які були коли-небудь створені не спростовують одне одного, а навпаки, доповнюють і при правильному комбінуванні можна отримувати нові способи мотивації. Деякі керівники вважають, що витрати коштів на удосконалення процесу мотивації не потрібні. Але насправді, мотивовані працівники дають велику віддачу, підвищуючи соціальний і економічний ефект підприємства. Так, на думку експертів, мотивовані працівники підвищують доходи компанії мінімум на 10\%, тому сучасний керівник повинен приділяти достатню частину робочого часу для вивчення та удосконалення процесів стимулювання персоналу. 3 огляду на всі перераховані вище фрактори, слід більш детально проаналізувати особливості персональної та групової мотивації сучасних підприємств, види та проблеми ефективного стимулювання.

Ключові слова: мотивація, управління персоналом, групова та персональна мотивація, поліпшення працездатності персоналу, демотивация, стимулювання.

This work is licensed under a Creative Commons Attribution 4.0 International License http://creativecommons.org/licenses/by/4.0/

Постановка проблеми та зв'язок з важливими науковими та практичними завданнями. На сьогоднішній день $є$ маса проблем мотивації, 3 якими стикаються компанії по всьому світу. Вивчивши деякі джерела, ми запропонуємо оптимальні рішення проблем і по можливості їх подальшого використання на вітчизняних підприємствах.

Так, в останні роки стає популярною концепція про те, що заробітна плата не єдиним мотиватором, однаково важливим для всіх працівників. Але, слід зазначити, що у тих чи інших людей існують різні потреби, які за ступенем значущості шикуються в «своєрідну чергу» або їх мотиваційний профіль. Дійсно, потреба тільки лиш в заробітку в мотиваційному профілі працівника далеко не завжди знаходиться на першому місці. Більш того, важливо відмітити, що знаючи мотиваційний профіль співробітника, цю потребу можна замінити іншими мотиваторами, які не є матеріальними [2].

Деякі вчені зазначають, що змістові теорії мотивації намагаються визначити потреби, які спонукають людей до дії, вони аналізують людські пот- реби та допомагають керівникам зрозуміти, які винагороди за працю люди цінуватимуть, а які - ні. Серед багатьох теорій мотивації виокремимо чотири основних, які вже стали класичними: А. Маслоу, К. Алдерфера, Д. Мак-Клелланда та Ф. Герцберга. Одним із перших біхевіористів, ученим, із праць якого керівники дізналися про складність людських потреб та їх вплив на мотивацію до праці, був Абрахам Маслоу [3]. В 40-х роках ХХ ст. він створив теорію ієрархії потреб особистості. Це була одна 3 перших спроб класифікації людських потреб за ступенем їх впливу на поведінку. Згідно з теорією потреби ранжуються на п'ять рівнів, що систематизовано у табл. 1 [3].

Як можна побачити 3 табл. 1, є два ступені потреб, первинні і вторинні, які дають усвідомлення того, як задовольнити потреби співробітників і як це відобразиться на їх мотивації в залежності від рівня. Соціологами та іншими експертами було проведено валідне дослідження серед працівників середньостатистичних підприємств. Результати дослідження показали основні типи потреб сучасних працівників, що наведено у табл. 2 . 
П'ять рівнів ранжування потреб особистості*

\begin{tabular}{|l|c|l|}
\hline \multicolumn{3}{|c|}{ Ієрархія потреб за Л. Маслоу } \\
\hline Ступінь потреб & Рівні & Потреби \\
\hline \multirow{2}{*}{ Первинні } & 1 & Фізіологічні \\
\cline { 2 - 3 } & 2 & Безпека і захист \\
\hline \multirow{3}{*}{ Вторинні } & 3 & Соціальні \\
\cline { 2 - 3 } & 4 & Повага \\
\cline { 2 - 3 } & 5 & Самореалізація \\
\hline
\end{tabular}

*Розроблено авторами на основі ієрархії потреб за А. Маслоу [3]

Таблиця 2

Основні типи потреб в середньостатистичних підприємствах [4]

\begin{tabular}{|c|c|c|c|}
\hline № & Тип потреб & $\begin{array}{l}\text { \% від } \\
\text { колективу } \\
\text { (колектив } \\
\text { прийнято } \\
\text { за } 100 \%) \\
\end{array}$ & Характеристика \\
\hline 1 & $\begin{array}{c}\text { Мисливці за } \\
\text { бонусами }\end{array}$ & 22 & $\begin{array}{l}\text { Як правило, їх більшість, вони шукають як матеріальну винагороду, так і } \\
\text { нематеріальне. Ідеальний варіант - подарункові сертифікати, туристичні } \\
\text { путівки. Цей сегмент більш ніж на половину представлений жінками (58\%). } \\
\text { Їх мало цікавлять заохочення, які змушують вийти за рамки компетенції. }\end{array}$ \\
\hline 2 & Домосіди & 20 & $\begin{array}{l}\text { Уникають заохочень, які змушують хоча б на якийсь час залишити рідних } \\
\text { (корпоративні виїзди, путівки). Для них важливо зберегти баланс між робо- } \\
\text { тою та особистим життям. Бажана нагорода - вихідний день. Цей сегмент } \\
\text { співробітників старше інших, на 54\% складається з чоловіків. }\end{array}$ \\
\hline 3 & Матеріалісти & 19 & $\begin{array}{l}\text { Таких найбільше цікавить слава, вітається тільки «золота монета». Кращий } \\
\text { спосіб мотивації - конкретні матеріальні блага: якщо не грошові, то система } \\
\text { бонусів } з \text { використанням каталогу подарунків. Зазвичай в таких співробіт- } \\
\text { ників спостерігається високий рівень незадоволеності роботою і, як прави- } \\
\text { ло, це жінки }(59 \%) \text {. }\end{array}$ \\
\hline 4 & Ув'язнені & 17 & $\begin{array}{l}\text { Найменш матеріально мотивовані співробітники. Їх найбільша мрія - сво- } \\
\text { бода. Найчастіше це люди, вже досягли певних результатів у житті, які ма- } \\
\text { ють стійке матеріальне становище. Для них важлива самореалізація, вони } \\
\text { шукають роботу, в якій частка контролю з боку керівника зведена до міні- } \\
\text { муму. Їх рекомендується заохочувати гнучким графіком, додатковими го- } \\
\text { динами відпочинку, можливістю участі в конференціях, виставках, нових } \\
\text { проектах. }\end{array}$ \\
\hline 5 & $\begin{array}{c}\text { Мисливці за } \\
\text { похвалою }\end{array}$ & 16 & $\begin{array}{l}\text { Їх найбільша потреба - визнання заслуг. Чи буде похвала супроводжуватися } \\
\text { грошовою премією, не має основного значення. Вони прагнуть зайняти ви- } \\
\text { соке соціальне становище. У більшості цей сектор представлений чоловіка- } \\
\text { ми (54\%). }\end{array}$ \\
\hline 6 & Ініціатори & 8 & $\begin{array}{l}\text { Відрізняються найбільшим задоволенням від роботи і лояльністю до робо- } \\
\text { тодавця. Вони люблять свою роботу і отримують від неї задоволення. Кра- } \\
\text { ща нагорода для них - особливий статус, що наблизить їх до Топ-рівня ком- } \\
\text { панії з керуючими функціями. Це переважно чоловіки - } 68 \% \text {, } 3 \text { яких 42\% - } \\
\text { молодше } 34 \text { років. }\end{array}$ \\
\hline
\end{tabular}

Аналіз останніх публікацій по проблемі. Останнім часом, все частіше зустрічаються проблеми плинністю кадрів в компаніях та мотивації персоналу. Проблеми щодо мотивації працівників описали: Большаков Д.В., Самко О.В., Воскобоєва О.С., Тертичний А. О., Кріловецкая А. Н., Труфанова С.В., Поваляєва А.І., Кузнєцов С.А та інші. Так само був вивчений і матеріал іноземними статей і видавництв, в написанні яких брали участь: Nigel Nicholson, Amanda Erickson, Melany Gallant, Lisa McQuerrey та інші. Аналізуючи роботи інших авторів, можна зрозуміти, що Україна і українські компанії стикаються з тими ж проблеми і що методи мотивації персоналу потрібні удосконалення і більш тривалі дослідження в цій cфepi.

Формулювання цілей дослідження. Основна мета полягає в пошуку ефективних інструментів щодо індивідуальної і групової мотивації працівників вітчизняних підприємств, а також розбір матеріалу i впровадження удосконалених мотиваційних методів в українські компанії.

Виклад основних результатів та їх обгрунтування. У кожного працівника є мотиваційний потенціал, як частина його загального трудового потен- 
ціалу. При цьому слід зазначити, що деякі працівники демонструють помітну відсутність прихильності, лояльності та відданості своїй роботі [5]. У своїй статті експерт Nigel Nicholson таку мотивацію описує як «мотиваційна енергія» що може впливати на зацікавленість працівників виконувати свої обов'язки, та, якщо брати під розрахунок всі індивідуальні інтереси співробітників, при спостереженні за роботою, можна правильно мотивувати співробітника виходячи 3 їх інтересів і додаючи вагомі елементи в робочий про- цес, розкриваючи його потенціал працівника на максимум.

Слід зазначити, що в Україні є певні проблеми щодо ефективності використання мотиваційних заходів, оскільки спостерігається деякі особливості в управлінні персоналом. Так, слід розглянути наступні загальні особливості в управлінні персоналом, що можуть тим чи іншим чином впливати на розробку та використання мотиваційних заходів.

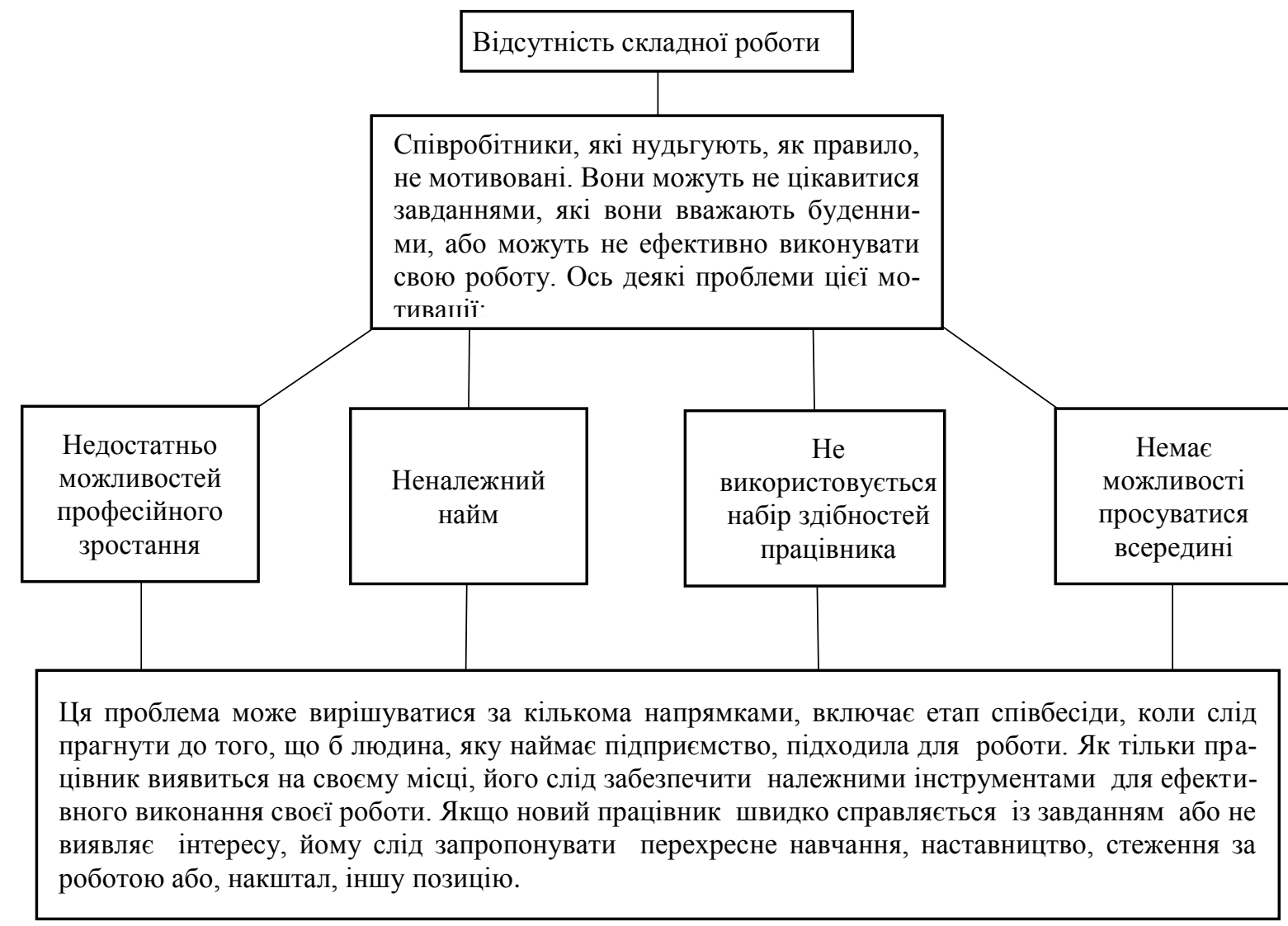

Рис. 2. Проблеми мотивації сучасних компаній * *розроблено авторами на основі [8]

Отже:

1.Незрозумілі очікування. Коли співробітники не повністю розуміють завдання, яке їм дали, за таких умов важко залишатися мотивованими. Професор Університету Південної Каліфорнії Річард Кларк пояснює, що якщо співробітник має сумнів в своєї здатності виконати завдання, його ентузіазм і прихильність компанії знижуються. [6].

2. Неможливість виконання. Деякі співробітники не мають навичок або інструментів, необхідних для виконання поставленого завдання. Це може привести до того, що співробітники будуть відчувати себе невпевнено в своій роботі і невпевнені в тому, чи виправдають очікування. Відсутність інструментів також може змусити співробітників відчувати, що їх компанія не інвестує в їх розвиток [6].

3.Недолік володіння. Працівникам важливо вірити, що вони мають частку в компанії, в якій вони працюють. Співробітники, які відчувають, що просто йдуть за наказами, менше вкладаються в кінцевий продукт, оскільки він не відображає їх ідеї і творчий підхід. Крім того, співробітники, які повинні постійно питати дозволу своїх менеджерів для вирішення навіть невеликих проблем, працюють менш ефективно і 3 меншою ймовірністю вирішать проблеми самостійHo [6]. 
4. Недолік компенсації. Працівники, які вважають, що їм не виплачують адекватну компенсацію за їх роботу відчувають себе недооціненими, що може викликати у них образу і вплинути на готовність старанно працювати. Отже, якщо не намагатись вирішити перераховані вище недоліки - надалі можна не тільки отримати низькі результати діяльності, а й втратити перспективних робочих.

Так, на іноземному сайті Saba.com [7], є розділ "How Lack of Motivation is Killing Your Company", що в перекладі означає "Як відсутність мотивації вбиває вашу компанію", де описані ефективні та нестандартні підходи щодо мотивації. Отже, розглянемо один із експериментів під назвою зазначеною на сайті, як «проблема зі свічками», щоб проілюструвати наскільки люди проваджені внутрішніми мотиваторами. У 1945 році гештальт-психолог Карл Дункер провів експеримент [7], щоб перевірити навички розв'язання проблем людини та коли був закладений «ментальний блок». Експериментом автори намагались пояснити, що проблеми 3 мотивацією можуть 3'явитися ще з самого початку, адже що для одного очевидно, для іншого ні. Виходячи із експерименту, слід зазначити, що люди не можуть бути мотивовані лише процесом, якщо не показати найпростіший спосіб досягнення цілей. Окрім зазначеного експерименту слід розглянути чотири основних блока проблеми щодо мотивації працівників у сучасних компаній. Так, підтримка певного рівня мотивації та залучення вже мотивованих співробітників може допомогти підвищити моральний дух, знизити плинність кадрів і створити більш динамічну і прибуткову діяльність. Хоча різні речі мотивують різних людей, є кілька демотивуючих факторів, які можуть негативно вплинути на ефективність діяльності підприємства. Розпізнавання та усунення цих факторів може допомогти поліпшити вашу організацію з багатьох напрямків [8].

Безумовно, мотивація співробітників пов'язана із продуктивністю, використанням трудового потенціалу, відповідних умов праці, якості комунікаційного процесу. Так, важливо збирати від співробітників зворотний зв'язок і покращувати умови праці на підприємстві, за таких обставин співробітники будуть більш зацікавлені роботою на підприємстві, в якому чують їх думку, тим більше, до цього можна додавати особисту похвалу співробітників за внесок в розвиток підприємства, а кращі пропозиції винагороджувати, що буде підвищувати мотивацію всієї команди.

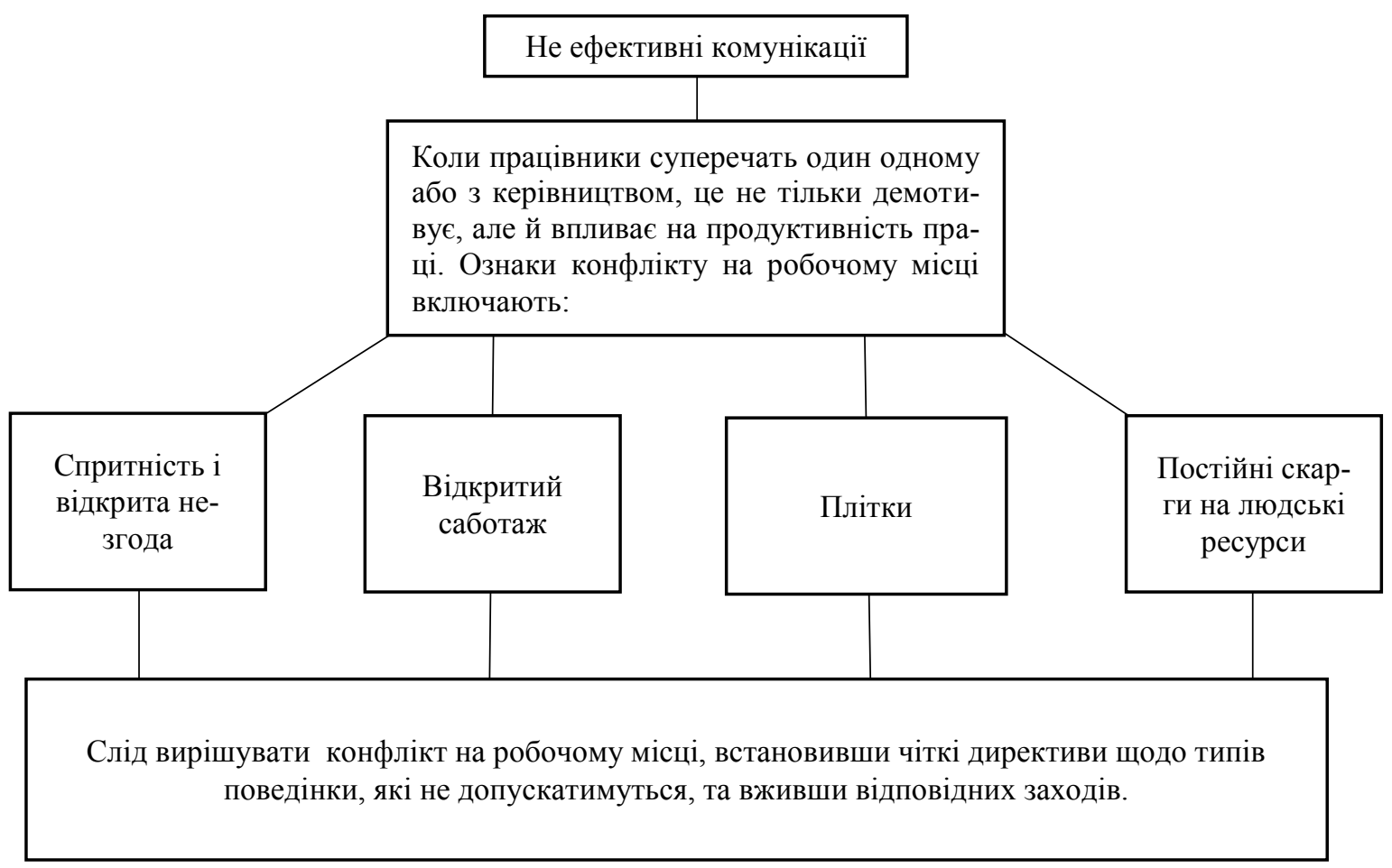

Рис. 3. Проблеми мотивації сучасних компаній* *розроблено авторами на основі [8]

Щорічно на підприємствах з'являються нові зміни: змінюється чисельність співробітників, зростає рівень конкуренції за клієнтів, збільшуються витрати і т.п. Але встановлені колись умови оплати, призначені відсотки і коефіцієнти залишаються незмінними. Настає момент, коли керівництво виявляється в заручниках встановленої кілька років тому системи мотивації персоналу. Такі зміни, як знижен- 
ня відсотка від прибутку або від виручки, можуть сприйматися персоналом негативно i провокувати зайву плинність кадрів. Хоча в той час, коли ці відсотки встановлювалися, компанія перебувала в інших умовах і на іншому рівні розвитку, і сьогодні ці умови можуть призводити до серйозних перекосів в оплаті праці [1]. Так, розглянемо наступний фактор, що впливає на мотивацію, рис .4.

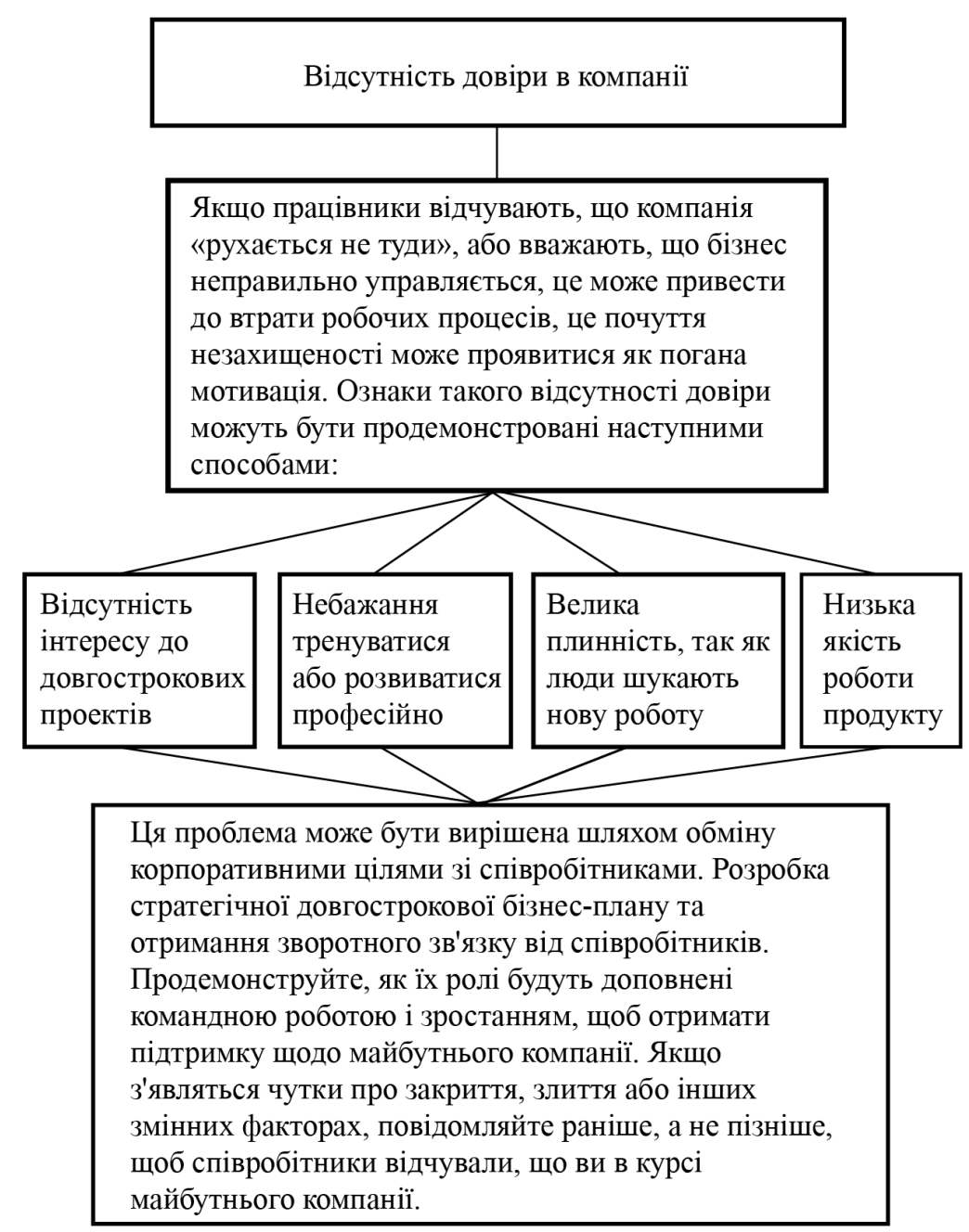

Рис. 4. Проблеми мотивації сучасних компаній * *розроблено авторами на основі [8]

Також потрібно розглянути питання із заробітною платою. Заробітна плата $є$ основною метою будь-якого співробітника, адже це винагорода за виконану роботу, вона необхідна для виживання і задоволення потреб людини в сучасному світі. Будь-яка людина, в залежності від своїх навичок, шукає роботу за чинниками обов'язків та заробітної плати, де порівнює необхідні від неї зобов'язання і винагороду за них. Важливо встановлювати заробітну плату на рівні конкурентів, для залучення більш висококваліфікованих співробітників і утримання їх на необхідний посаді, тобто приділяти індивідуальну увагу. На рис. 5 наведені наслідки відсутності індивідуального підходу до працівників.
Висновки та перспективи подальших досліджень. В сучасних умовах, коли працівник має доступ до будь-якої інформації та може порівнювати підприємства між собою самостійно, важливо не відставати від конкурентів, створювати такі умови праці що вплинуть на зростання мотивації до праці кожного працівника . Так, слід проводити постійні пошуки вирішення проблем з мотивацією персоналу, аналізувати причини плинності кадрів, контролювати робочі процеси, фізичний та психологічний стан працівників та інтерес до роботи, якість комунікацій тощо.Не варто вважати, що всі запропоновані експертами способи мотивації ефективні за будь яких умов, потрібно досліджувати дану область більш активно, 


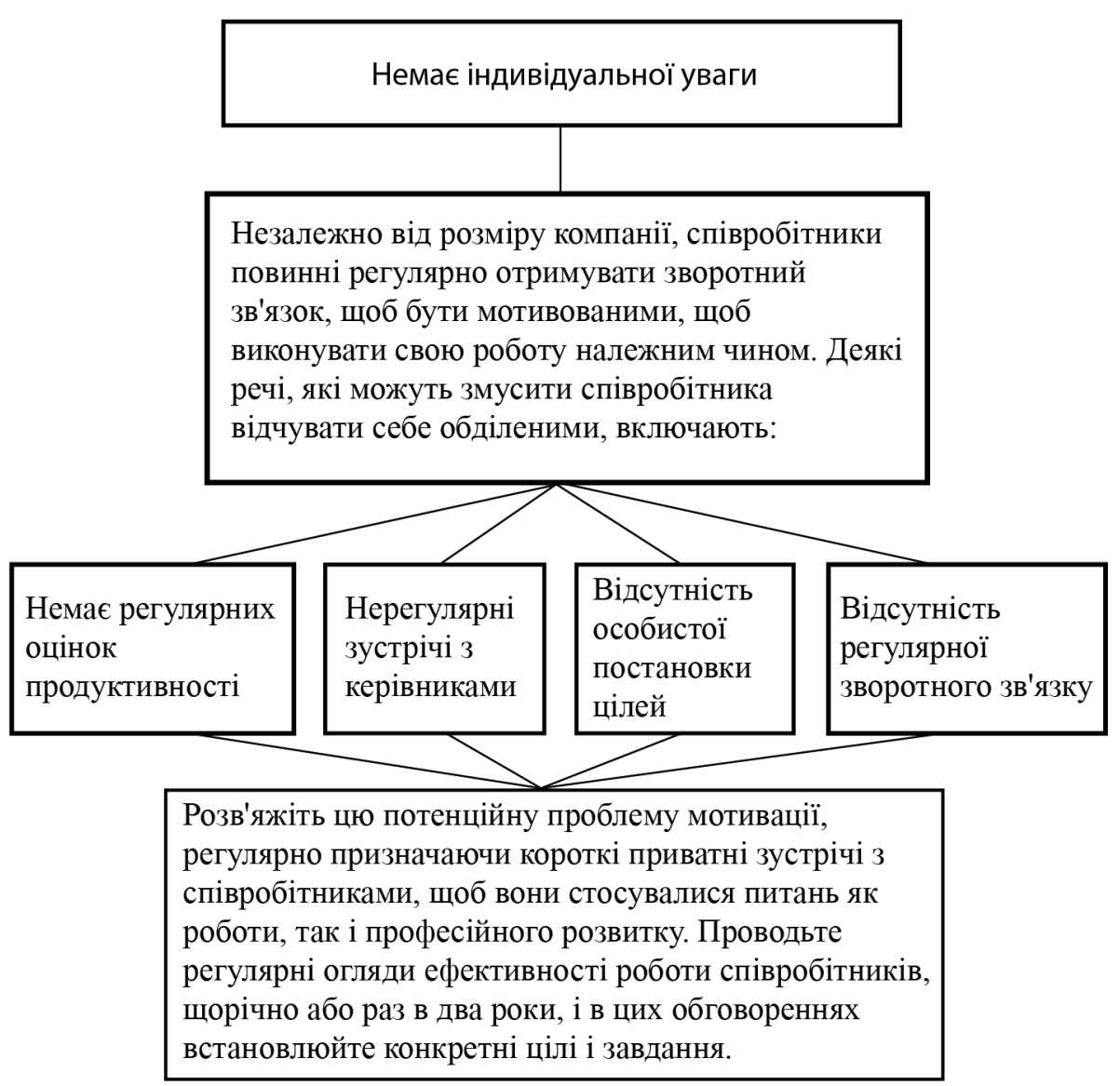

Рис. 5. Проблеми мотивації сучасних компаній* *розроблено авторами на основі [8]

аналізувати специфіку діяльності підприємства, внутрішні та зовнішні проблеми щодо управління персоналом, а саме способів його мотивації і обмінюватися інформацію в цій області з іншими дослідниками та експертами, для створення більш відповідної концеп- ції мотивації в сучасних умовах господарювання, враховуючи що мотивація персоналу безпосередньо впливає на всі трудові процеси та на прибутковість підприємства.

\section{Література}

1. Тренинговая компания «Бизнес Партнер»: [Веб-сайт]. URL: https://training-partner.ru/staty/problemymotivacii-personala.html (дата звернення: 01.04.2020).

2. Сиденко Б. В., Величко о О. О. Проблема мотивации работников на украине в современных условиях // Донецкий национальный университет экономики и торговли имени Михаила Туган-Барановского. 2019.1 січня. (№ 1). С. 1-2.

3. Змістові теорії мотивації // Навчальні матеріали онлайн: [Веб-сайт]. URL: https://pidruchniki.com/12090613/menedzhment/zmistovi_teoriyi_motivatsiyi (дата звернення: 01.04.2020).

4. Проблемы построения эффективной системы мотивации: [Веб-сайт]. URL: http://www.nbuv.gov.ua/articles/crimea/2006/123.pdfhttp://zt.knteu.kiev.ua/files/2012/03(62)2012/3_12_21.pdf ( дата звернення: 01.04.2020).

5. Harvard Business Publishing: [Website]. URL: https://hbr.org/2003/01/how-to-motivate-your-problempeople (viewed on: 01.04.2020).

6. Приклади мотиваційного питання в організації // Azcentral: [Website]. URL: https://yourbusiness.azcentral.com/examples-motivational-issue-organization-13314.html (viewed on: 01.04.2020).

7. Як відсутність мотивації вбиває вашу компанію // Saba: [Website]. URL: https://www.saba.com/uk/blog/how-lack-of-motivation-is-killing-your-company (viewed on: 01.04.2020). 
8. П'ять головних проблем мотивації працівників // Chron: [Website]. URL: https://work.chron.com/topfive-employee-motivation-problems-22613.html (viewed on: 01.05.2020).

9. Потапцева С. Ю. Значение мотивации персонала в современном менеджменте // Управління розвитком. 2011. №1. С. 7-8.

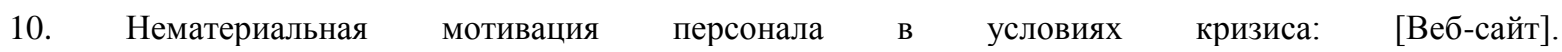
URL: http://nta.com.ua/uploads/articles/Nematerialnaya_motivatiya.pdf (дата звернення: 01.04.2020).

11. Мотиваційне середовище: [Веб-сайт]. URL: http://www.nbuv.gov.ua/articles/crimea/2006/123.pdf (дата звернення: 01.04.2020).

12. Балабанова Л.В., Сардак О.В. Управління персоналом: підручник. К.: центр учбової літератури, $2011.468 \mathrm{c}$.

13. Мотивація на робочому місці: [Веб-сайт]. URL: http://www.motivation-tools.com/workplace/ (дата звернення: 01.04.2020).

Стаття надійшла 10.04.2020

Стаття прийнята до друку 24.04.2020

Доступно в мережі Internet 11.07.2020

Козак Е.Б.

кандидат экономических наук, доцент кафедра менеджмента и логистики E-mail: kozakkate.coach@gmail.com ORCID ID: 0000-0002-8099-6607
Левчук Ю.С

старший преподаватель кафедра менеджмента и логистики E-mail: Levchyk_onaft@ukr.net ORCID ID: 0000-0001- 7417-2866

Прунчак Н.H.

студент 4 курса фракультета менеджмента, маркетинга и логистики Одесская национальная академия пищевых технологий ул. Канатная, 112, г. Одесса, Украина, 65039 E-mail: tiktonik199730@gmail.com ORCID ID: 0000-0001-9713-7692

\section{ИССЛЕДОВАНИЕ ОСНОВНЫХ ПРОБЛЕМ МОТИВАЦИИ РАБОТНИКОВ ПРЕДПРИЯТИЯ}

В течение многих лет, в отечественные компании не использовали улучшения процессов мотивации или системы мотивации в целом, в отличие от зарубежных, но в настоящее время, показатель условий мотивации в украинских компаниях начал расти и в этой статье мы рассмотрим, как можно совершенствовать процесс персональной и групповой мотивации в организациях. Все существующие способы не являются идеальными и требуют индивидуального использования, а также доработок, которые мы попытаемся рассмотреть в данной статье.

Используя всевозможную мировую практику, можно уверенно сказать, что большинство крупнейших мировых компаний выросло благодаря своим сотрудникам (это неоднократно написано компаниями в их обращениях к прессе). Лидирующие мировые гиганты не скрывают того фрактора, что их стимулирование сотрудников находиться на высшем уровне и постоянно совершенствуется в зависимости от мировых тенденций и новых разработок в сфере мотивации, поэтому так важно исследование мотивации персонала на любом предприятии с постоянным слежением на мировое движение.

Мировая практика говорит, что все теории мотивации, которые были когда-либо созданы, не опровергают друг друга, а наоборот, дополняют и при правильном комбинировании, можно получить совершенно новые способы мотивации, которые при индивидуальном применении к персоналу дают отличный эффрект. Многие руководители заблуждаются насчет мотивации, считая, что это не нужные затраты средств и ресурсов, но на самом деле, сотрудники, которые мотивированы, дают большую отдачу, повышая социальный и экономический эффект. Если говорить отдельно про экономический эффект, то мотивированная группа сотрудников, которая следует целям компании, повышают доходы компании минимум на 10\%, а пределу нет конца, поэтому хороший руководитель должен тратить достаточную часть своего рабочего времени и ресурсов, для изучения стимулирования сотрудников, для повышения всех показателей предприятия. Учитывая все вышеперечисленные факторы, мы изучим дальнейшую статью, написанную на основе всевозможных отечественных и зарубежных источников.

Ключевые слова: мотивация, управление персоналом, групповая мотивация, индивидуальная мотивация, улучшения работоспособности персонала, развитие трудового потенциала персонала, кадры, демотивация. 


\author{
Kozak K. \\ Ph.D., Associate Professor \\ Department of Management and Logistics \\ E-mail: kozakkate.coach@gmail.com \\ ORCID ID: 0000-0002-8099-6607
}

\author{
Levchuk Yu. \\ Assistant \\ Department of Management and Logistics \\ E-mail: Levchyk_onaft@ukr.net \\ ORCID ID: 0000-0001- 7417-2866
}

Prunchak M.

The student of the fourth grade of Management, Marketing and Logistics Faculty

Odessa National Academy of Food Technologies

Kanatna str., 112 Odesa, Ukraine, 65039

E-mail: tiktonik199730@gmail.com

ORCID ID: 0000-0001-9713-7692

\section{RESEARCH OF THE MAIN PROBLEMS OF MOTIVATION OF EMPLOYEES AT THE ENTERPRISES}

For many years, domestic companies have not used improvement of motivation processes or motivation system in general, unlike foreign ones, but now, the indicator of motivation conditions in Ukrainian companies has begun to grow and in this article we will consider how to improve the process of personal and group motivation in organizations. All existing methods are not ideal and require individual use, as well as refinements, which we will try to consider in this article. Using various world practices, it is safe to say that most of the world's largest companies have grown thanks to their employees (this is repeatedly written by companies in their appeals to the press). The world's leading giants do not hide the fact that their employee incentives are at the highest level and are constantly improving depending on global trends and new developments in motivation, so it is important to study staff motivation in any company with constant monitoring of the global movement.

World practice says that all theories of motivation that have ever been created do not refute each other, but on the contrary, complement and with the right combination, you can get completely new ways of motivation, which when applied individually to staff give a great effect. Many managers are mistaken about motivation, believing that it is not worth cost and resources, but in fact, the employees who are motivated give a greater return, increasing the social and economic impact. Speaking separately about the economic effect, a motivated group of employees who follow the company's goals increase the company's income by at least $10 \%$, and there is no end to the limit, so a good leader must spend enough time and resources to study employee incentives to improve all indicators of the enterprise. Taking into account all the above factors, we will study the following article, written on the basis of various domestic and foreign sources.

Key words: motivation, personnel management, group motivation, individual motivation, staff performance improvements, staff work potential development, personnel, demotivation.

\section{References}

1. Treningovaya kompaniya «Biznes Partner». Retrieved April 1, 2020, from https://trainingpartner.ru/staty/problemy-motivacii-personala.html

2. Sidenko, B. V., \& Velichko, O. O. (2019). Problema motivatsii rabotnikov na ukraine v sovremennyih usloviyah. Donetskiy natsionalnyiy universitet ekonomiki i torgovli imeni Mihaila Tugan-Baranovskogo, (1), 1-2.

3. Zmistovi teorii motyvatsii. Navchalni materialy onlain. Retrieved April 1, 2020, from https://pidruchniki.com/12090613/menedzhment/zmistovi_teoriyi_motivatsiyi

4. Problemyi postroeniya effektivnoy sistemyi motivatsii. Retrieved April 1, 2020, from http://www.nbuv.gov.ua/articles/crimea/2006/123.pdfhttp://zt.knteu.kiev.ua/files/2012/03(62)2012/3_12_21.pdf

5. Harvard Business Publishing. Retrieved April 1, 2020, from https://hbr.org/2003/01/how-to-motivate-yourproblem-people

6. Pryklady motyvatsiinoho pytannia $v$ orhanizatsi. Azcentral. Retrieved April 1, 2020, from https://yourbusiness.azcentral.com/examples-motivational-issue-organization-13314.html

7. Yak vidsutnist motyvatsii vbyvaie vashu kompaniiu. (2013). Saba. Retrieved April 1, 2020, from https://www.saba.com/uk/blog/how-lack-of-motivation-is-killing-your-company

8. Piat holovnykh problem motyvatsii pratsivnykiv. (2018). Chron. Retrieved May 1, 2020, from https://work.chron.com/top-five-employee-motivation-problems-22613.html 
9. Potaptseva, S. Yu. (2011). Znachenye motyvatsyy personala v sovremennom menedzhmente. Upravlinnia rozvytkom, (1), 7-8.

10. Nematerialnaya motivatsiya personala $v$ usloviyah krizisa. (2009). Retrieved April 1, 2020, from http://nta.com.ua/uploads/articles/Nematerialnaya_motivatiya.pdf
11. Motyvatsiine seredovyshche.
Retrieved
April
1,
2020 ,
from http://www.nbuv.gov.ua/articles/crimea/2006/123.pdf

12. Balabanova, L. V., \& Sardak, O. V. (2011). Upravlinnia personalom. Kyiv: tsentr uchbovoi literatury.

13. Motyvatsiia na robochomu mistsi. Retrieved April 1, 2020, from http://www.motivationtools.com/workplace/

Received 10 April 2020

Approved 24 April 2020

Available in Internet 11.07.2020

Цитування згідно ДСТУ 8302:2015

Козак К.Б., Левчук Ю.С., Прунчак М.М. Дослідження основних проблем щодо мотивації працівників підприємства // Економіка харчової промисловості. 2020. Т.12, вип. 2. С.45-54. doi: 10.15673/fie.v12i2.1739

Cite as APA style citation

Kozak, K., Levchuk, Yu., \& Prunchak, M. (2020). Research of the main problems of motivation of employees at the enterprises. Food Industry Economics, 12(2), 45-54. doi: 10.15673/fie.v12i2.1739 